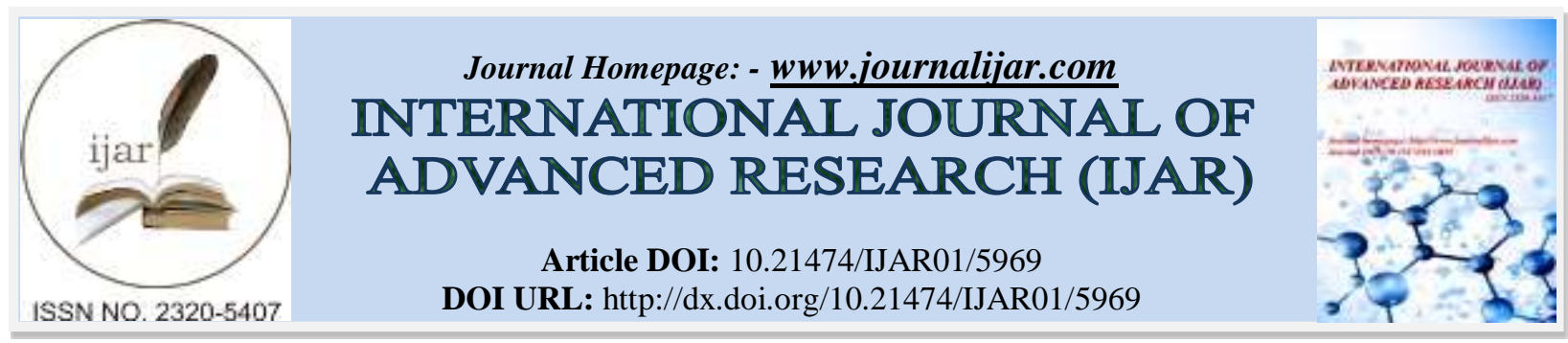

RESEARCH ARTICLE

\title{
A TRACER STUDY ON THE GRADUATES OF BACHELOR OF SCIENCE IN PSYCHOLOGY OF URS PILILLA AY's 2010-2013.
}

Dr. Jocelyn L. Gagalang ${ }^{1}$, Prof. Liezel R. Francisco ${ }^{2}$ and Prof. Bernardita O. Regalado ${ }^{3}$.

1. Dean, College of Social Sciences, University of Rizal System Pililla, Rizal, Philippines.

2. Program Head, College of Social Sciences, University of Rizal System Pililla, Rizal, Philippines.

3. Coordinator, General Education, University of Rizal System Pililla, Rizal, Philippines.

\section{Manuscript Info}

\section{Manuscript History}

Received: 04 October 2017

Final Accepted: 06 November 2017

Published: December 2017

\section{Key words:-}

Tracer Study BS Psychology Extent HR Courses College Life Graduates.

\section{Abstract}

This study primarily aimed to determine the employment aspects and assess the extent of the contributory factors of the course that helped the graduates to be developed; extent of the course on the overall college life experience and the extent of life satisfaction of the graduates of Bachelor of Science in Psychology of the University of Rizal System Pililla, Academic Years 2010-2013.

The respondents were the seventy (70) graduates of all the batches mentioned. The total enumeration was considered in this study, however, there were only forty-seven (47) or $67.14 \%$ who responded among the graduates of BS Psychology from the University of Rizal System Pililla Campus.

The variables included in the profile of respondents were sex, age, civil status, first choice course, source of finances and personal monthly income.

This study was concerned with the extent of the contributory factors of the course that helped the graduates to be developed; the extent of the course on the overall college life experience; and the extent of life satisfaction among BS Psychology graduates.

This research study utilized the descriptive method of research. The data-gathering tool was the Graduate Tracer Study (GTS) Questionnaire adapted from the Commission on Higher Education (CHED).

Based on the findings of the study, it can be concluded that majority of the respondents were female, trainable, young adults, responsible single, have chosen to pursue BS Psychology as their first choice course, financially supported by parents in college and belonged to above poverty line.

Majority of the BS Psychology graduates are offered to work in private institutions or establishments due to numerous vacant positions related to the course; are engaged in contractual or casual status due to limited permanent positions both in public and private institutions; with first job title of an HR Assistant or HR Office Staff; involved in technical or professional work which have opportunities for professional development; determined to apply their acquired knowledge and skills right after graduation; got hired in less than two (2) months after 
graduation as walk-in aspirant or direct application; whose job choice was influenced by professional environment; attribute the job offer to their competent talents, skills and hands-on activities; consider their occupation as complemented to their qualification.

The graduates believe that BS Psychology course has developed them to be competent team player; are agreeable that the course has optimistic impact on them; and are contented with their present life. In order to meet the varying demands in diverse workplace, they feel the essence of having more human resource-related subjects and relevant trainings to be included in the curriculum.

Copyright, IJAR, 2017. All rights reserved.

\section{Introduction:-}

Psychology is the scientific study of human behavior, eventually, a Psychology degree can equip someone with a very valuable perspective and psychological knowledge can bring unique insights into human thinking, emotion, motivation and behavior. Psychology graduates understand individual differences, diversity and ethics. Psychological literacy means being able to apply these knowledge and skills to real life contexts. ${ }^{1}$

Employment of Psychologists by Kendra Cherry listed that around 20 percent were employed in health care, primarily in offices of mental health practitioners, physicians, outpatient mental health and substance abuse centers, and private hospitals. Educational institutions employed 29 percent of psychologists in positions other than teaching, such as counseling, testing, research, and administration. Government agencies at the State and local levels employed psychologists in public hospitals, clinics, correctional facilities, and other settings. After several years of experience, some psychologists, usually those with doctoral degrees, enter private practice or set up private research or consulting firms. In addition to the previously mentioned jobs, many psychologists held faculty positions at colleges and universities and as high school psychology teachers. ${ }^{2}$

In connection to this, employers need people with communication skills; the ability to collect, organize, analyze and interpret data; and an understanding of human behavior. Psychology graduates may work in human resources or communications, while further education will open paths toward clinical practice and research.

As a result, a Bachelor of Science in Psychology program provides students with general education in theoretical perspectives related to the field; it does not offer professional training. Students who obtain a BS degree in Psychology may work in mental health facilities, government or business, but they will not be qualified for jobs as professional psychologists without further education.

Undergraduate psychology programs are generally designed to teach students about the brain, human behavior and social interactions through scientific approaches. Many schools offer both Bachelor of Science (BS) and Bachelor of Arts (BA) programs in psychology; BS programs often include more coursework and labs related to math and science, such as neurobiological processes and the mechanics of the brain. Some B.S. in Psychology programs allow students to focus their studies in a subfield of Psychology, such as mental health, forensic psychology or developmental psychology. Students can acquire an understanding about the ethics of psychology, especially in regard to interacting with clients.

Throughout this program, students may participate in research, practicum or clinical hours, as well as independent studies or capstone projects related to an area of interest, such as human behavior or development. Students may also have the opportunity to become members of Psi Chi (the National Honor Society in Psychology) or student chapters of the American Psychological Association and the American Psychological Society.

Students applying to a bachelor's degree program need to have a high school diploma or its equivalent. Some colleges may also ask applicants to submit an activity resume or an essay.

In addition to this, Bachelor of Science in Psychology programs offer students foundational knowledge in analytical reasoning, cognition, statistics and subfields of psychology. Furthermore, students can improve their skills in 
technical writing, critical thinking and research. Students may encounter course topics such as: Abnormal Psychology; Clinical Psychology; Aging and Adulthood; Social Development and Psychology; and Personality theories.

Further, students who earn a BS in Psychology may pursue entry-level positions in psychology-related careers. Individuals may find work in mental health facilities, halfway houses, crisis center hospitals, detention centers or psychiatric hospitals. Some graduates may find positions as psychiatric assistants, assistant directors or administrators. According to the US Bureau of Labor Statistics, psychiatric aides earned an average salary of $\$ 26,680$ in May 2012). ${ }^{3}$ The number of employed psychiatric aides was projected to rise by $15 \%$ from 2010 to 2020 .

Students who want to become professional psychologists must enter a graduate program in Psychology, usually a Doctor of Psychology or a Doctor of Philosophy in Psychology. At the graduate level, students can focus their studies on one specific area, such as clinical psychology, developmental psychology or health psychology. Some graduate programs offer a dual program that combine the Doctor of Philosophy program with a master's degree in a different field, such as public policy. Psychologists who plan to work with clients are also required to earn state licensure. ${ }^{4}$

In view of this, the University of Rizal System-Pililla Campus offers Bachelor of Science in Psychology under the College of Social Sciences. The course has the goal to provide students with rigid training in the three settings or fields in Psychology namely; educational, industrial and clinical to further prepare them as future Psychology practitioners. Moreover, the graduates of this program are expected to acquire and develop sufficient knowledge and skills needed to qualify for a position related to the course.

This study aimed to determine the employment aspects and assess the extent of the contributory factors of the course that helped the graduates to be developed; extent of the course on the overall college life experience and the extent of life satisfaction of the graduates of Bachelor of Science in Psychology of URS Pililla AY's 2010-2013.

This study is beneficial to the university administrators, faculty members, students, curriculum revision technical working group and stakeholders. Based on the gathered data, the university administrators can formulate and implement policies that can help improve the course offerings. The faculty members can integrate the necessary and most appropriate teaching-learning conditions, experiences and requirements that can facilitate the development of more skilled, more educated and more sought-after graduates of these programs. The students can also gain insights on what opportunities and threats await them, hence, become more eager to learn and develop more strategic approaches to employability. The curriculum TWG can have a closer look on what significant curricular revisions can be made in order to match the concepts and experiences to be provided to the demands of today's modern society. Lastly, the stakeholders can have a clearer picture on what employability rate the course has to offer.

\section{Objectives:-}

This study aimed to determine the employment aspects and assess the extent of the contributory factors of the course that helped the graduates to be developed; extent of the course on the overall college life experience and the extent of life satisfaction of the graduates of Bachelor of Science in Psychology of URS Pililla AY's 2010-2013.

It specifically aimed to:

1. Determine the profile of BS Psychology graduates in terms of sex, age, civil status, first choice course, source of finances and personal monthly income.

2. Determine the status of BS Psychology graduates with respect to their employer, employment status, nature of work, job hunting period, reason for getting the job and reason for accepting the job.

3. Determine the extent of the contributory factors of the course that helped the graduates to be developed.

4. Determine the extent of the course on the overall college life experience.

5. Determine the extent of life satisfaction of the BS Psychology graduates.

6. Determine the course(s) training program(s) that need(s) to be included in the curriculum to enable BS Psychology graduates to compete well in the labor market. 


\section{Literature Review:-}

What courses are considered most in demand in the job market? What academic experiences and learning in college that the graduates find very useful in the workplace?

These are just some of the questions answered in the Graduate Tracer Study questionnaire authored by the Commission on Higher Education and utilized by various state colleges and universities in the country.

The result of the study, which tracked down tertiary graduates from 2001 to 2004, can help Higher Education Institutions (HEIs) like the CSC to be more strategic in developing their curricula as well as on deciding on program offerings, staffing patterns and faculty development. It can also gauge the effectiveness and/or responsiveness of the degree programs which the graduates completed in the particular school, specifically on identifying the cluster of courses/subjects that the graduates found most useful in their workplaces.

In the national policy level, result of the tracer study can be utilized by the Commission to put up an Annual Higher Education Advisory for parents and students. The advisory contained information such as most demanded jobs, highest hiring (starting) rate and the types of schools most desired by employees. It also provides valuable information in terms of budgetary priorities for higher education, particularly state colleges and universities where normative financing is applied. ${ }^{5}$

According to an online article, a tracer study is an approach which widely being used in most organization especially in the educational institutions to track and to keep records of their students once they have graduated from the institution. It is the follow-up of graduates of higher education or institutes. Its aim is to evaluate one's progress up to the time he or she gets a job. ${ }^{6}$

Other findings that may be generated from the tracer study are: type of graduates who are most employable, academic experiences (competencies learned in college) that the graduates find very useful in the workplace, and personal academic background of graduates that can determine employability.

With this research, CHED would be able to formulate packaged assistance programs to develop and/or enhance higher education programs that would promote the country's global competitiveness.

On the other hand, the CSC, through its Research Services, aims to institutionalize the conduct of the tracer study at the CSC level to also achieve the same benefits that can be derived from tracking down employment status of its alumni. The result of the study can contribute, among others, in strengthening policies and guidelines in attaining relevance and responsiveness of CSC's curricular offerings. ${ }^{7}$

One of the major factors for underemployment and the difficulty in finding jobs is the inability of graduates to meet the necessary skills and competencies required by the industry.

According to the National Statistics Office, the unemployment rate in April 2012 is at 6.9 percent or 2.803 million while the underemployment rate is at 19.3 percent (7.312 million). In its April 2012 Labor Force Survey, the NSO revealed that more than half or 51.7 percent of the unemployed were in the age group of 15-24. Of this number, 32.8 percent are high school graduates, 13.8 percent are college undergraduates, and 21.0 percent are college graduates.

For the past years, the Commission on Higher Education (CHED) has been closely working with industry stakeholders to address the job mismatch. Industry representatives are being involved in the development of curricula and standards, on-the-job-training programs, apprenticeships, faculty immersion, assessment-based talent development and other activities. ${ }^{8}$

In a bid to address the growing job mismatch in the country, CHED, in collaboration with the De La Salle University College of Education conducted a national Graduate Tracer Study (GTS) to determine the employability of graduates based on their respective disciplines.

Through the study, CHED hopes to assess the issues concerning employability and the relevance of higher education programs vis-a-vis expectations of the employers. It will use the results of the study to monitor the quality of programs offered in the Higher Education Institutions (HEIs); provide incentives to institutions; prioritize or de- 
prioritize courses; determine the basis for allocating scholarships; and investigate whether 21 st century skills are properly and adequately taught to college students.

The commissioned study was conducted via an online survey that ran until October 31, 2012. Some 58,000 tertiarylevel graduates (from batch 2006-2010) from 837 HEIs all over the country (including state universities and colleges, locally funded universities and colleges, and private universities and colleges) were targeted in the study.

This tracer study was composed of getting demographic profile of the respondents. For instance, according to De Paulo (2006), single people might be expected to be seen as less committed to their jobs and less likely to succeed as employees compared to married people. On the other hand, some anecdotal evidence suggests that people expect single individuals to be able and willing to work longer hours than married people because married people may have obligation outside of work and this might lead people to favor singles in employment decisions. ${ }^{9}$

Likewise, monthly income is considered since, according to a study made the National Economic and Development Authority (NEDA), every Filipino family consisting five members should be earning on the average a combined monthly income of Php 7,019 in order to meet the basic needs. ${ }^{10}$

This was also relevant to the study of Coleman, as cited by Evangelista, et.al., (2015), changing demographics were causing employers to re-evaluate benefits plans and work-life programs so they were fair to an ever diversifying workforce.

\section{Theoretical Framework:-}

This study was anchored on the Human-Capital Theory. This is a modern extension of Adam Smith's explanation of wage differentials by the so-called net (dis)advantages between different employments. The costs of learning the job are a very important component of net advantage and have led economists such as Gary S. Becker and Jacob Mincer to claim that, other things being equal, personal incomes vary according to the amount of investment in human capital; that is, the education and training undertaken by individuals or groups of workers. A further expectation is that widespread investment in human capital creates in the labor-force the skill-base indispensable for economic growth.

\section{Methodology:-}

This research study utilized the descriptive method of research. The data-gathering tool was the Graduate Tracer Study (GTS) Questionnaire adopted from the Commission on Higher Education (CHED). The data-gathering tool was the CHED-prescribed questionnaire that was administered to the graduates. In the data-gathering process, the researchers used all the possible means of communicating with the BS Psychology graduates. They have contacted them through calls, texts messages, face-to-face communication, Facebook, messenger, email and through friends, acquaintances and students. Answered questionnaires were then forwarded either through personal, email and messenger applications. The data gathered were tallied, treated statistically, analyzed and interpreted. 
Conceptual Framework:INPUT

\author{
Profile of the Respondents \\ (1) Sex \\ 口 Age \\ ( Civil Status \\ 4 First Choice Course \\ 4 Source of Finances \\ $\mathrm{P}$ Personal Monthly \\ Income
}

\section{Status of BS Psychology} Graduates

[ Employer

- Employment Status

4 Nature of Work

$\square$ Job Hunting Period

प Reason for Getting The Job

प Reason for Accepting The Job

\section{Contributory Factors that} Develop Graduates

\section{College Life Experience}

Life Satisfaction of the BS Psychology Graduates

Course(s) training program(s) needed
PROCESS

OUTPUT

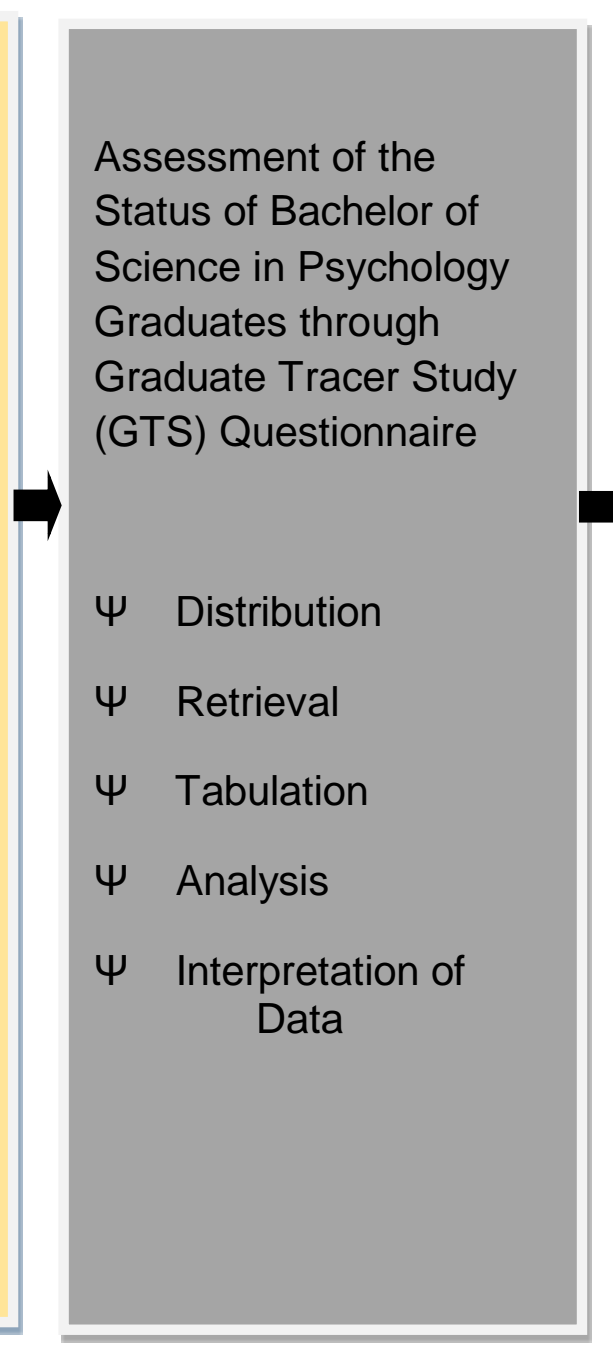

Assessed Extent of the Status of the Graduates of Bachelor of Science in Psychology

Directory of BS Psychology Graduates

Subjects of the Study:-

The subjects of the study were the 70 graduates of Bachelor of Science in Psychology of the University of Rizal System Pililla, Rizal, Academic Years 2010-2013.

Table 1:- Distribution of Respondents

\begin{tabular}{|c|c|c|c|}
\hline Academic Year & $\begin{array}{c}\text { Total Number of } \\
\text { Graduates }\end{array}$ & $\begin{array}{c}\text { Graduates who } \\
\text { Responded }\end{array}$ & \% \\
\hline $2009-2010$ & 17 & 12 & 70.59 \\
\hline $2010-2011$ & 14 & 9 & 64.29 \\
\hline $2011-2012$ & 19 & 9 & 47.37 \\
\hline $2012-2013$ & 20 & 17 & 85.00 \\
\hline Total & 70 & 47 & 67.14 \\
\hline
\end{tabular}

There were seventy (70) graduates of all the batches mentioned. The total enumeration was considered in this study, however, there were only forty-seven (47) who responded. Twelve (12) among seventeen (17) for Academic Year 2009-2010, nine (9) among fourteen (14) for 2010-2011, nine (9) among nineteen (19) for 2011-2012, and seventeen (17) among twenty (20) graduates of Academic Year 2012-2013 or 67.14 percent of the total population responded due to change of residence, proximity of work and lack of cooperation. 
Likert Scale:

Part 1

Scale
5
4
3
2
1

Part 2

Scale
5
4
3
2
1

Part 3

Scale
5
4
3
2
1
Scale Range
$4.20-5.00$
$3.40-4.19$
$2.60-3.39$
$1.80-2.59$
$1.00-1.79$

Scale Range

$4.20-5.00$

$3.40-4.19$

$2.60-3.39$

$1.80-2.59$

$1.00-1.79$
Verbal Interpretation

Very Much Contributory

A Lot Contributory

Some Contributory

Very Little Contributory

Not at all Contributory

\section{Verbal Interpretation}

Strongly Agree

Agree

Neutral

Disagree

Strongly Disagree

Results and Discussions:-

Profile of BS Psychology Graduates in Terms of Sex, Age, Civil Status, First Choice Course, Source of Finances and Monthly Income.

Table 2:- Frequency, Percentage and Rank Distribution of the Respondents in Terms of Sex

\begin{tabular}{|l|l|c|c|c|}
\hline \multicolumn{1}{|c|}{ Sex } & Frequency & Percent & Rank \\
\hline & Male & 16 & 34.00 & 2 \\
\hline & Female & 31 & 66.00 & 1 \\
\hline & Total & 47 & 100.00 & \\
\hline
\end{tabular}

As shown in the table, the discipline is dominated by female graduates since most males are still engaged with the culturally-bound masculine work.

The data imply that there were more female who preferred to graduate with the course of Bachelor of Science in Psychology who also were employed because of their possessed competencies in the field of behavioral science.

Table 3:- Frequency, Percentage and Rank Distribution of the Respondents in Terms of Age

\begin{tabular}{|l|l|c|c|c|}
\hline \multicolumn{2}{|l|}{ Age } & Frequency & Percent & Rank \\
\hline & below 21 & 6 & 14.60 & 3 \\
\hline & $22-25$ & 15 & 36.60 & 2 \\
\hline & $26-29$ & 17 & 41.50 & 1 \\
\hline & 30 and above & 3 & 7.30 & 4 \\
\hline & Total & 41 & 100.00 & \\
\hline No Answer & & 6 & & \\
\hline Total & 47 & & \\
\hline
\end{tabular}

It can be gleaned from the table that in terms of age, the Psychology graduates are in their middle to late twenties, since they graduated based on expected age or timeline as regular students. 
It infers that the respondents were young adults who are trainable, expected to be aiming for stable jobs in order to establish their own career and/or own families.

Table 4:- Frequency, Percentage and Rank Distribution of the Respondents in Terms of Civil Status.

\begin{tabular}{|l|c|c|c|}
\hline \multicolumn{1}{|c|}{ Civil Status } & Frequency & Percent & Rank \\
\hline Single & 30 & 63.80 & 1 \\
\hline Married & 17 & 36.20 & 2 \\
\hline Total & 47 & 100.0 & \\
\hline
\end{tabular}

It can be gleaned from the table that single status outnumbered the married status, since most of the Psychology alumni would like to prioritize their career in order to fulfill their dreams.

It indicates that employers appoint people who are single since they think they are more committed to their jobs and likely to accept challenges and responsibilities compared to married ones.

This supports some anecdotal evidences, as cited by Evangelista, et. al. (2015), that people expect single individuals to be able and willing to work longer hours than married people because married people may have obligation outside of work and this might lead people to favor singles in employment decisions.

Table 5:- Frequency, Percentage and Rank Distribution of the Respondents in Terms of First Choice Course

\begin{tabular}{|l|c|c|c|}
\hline \multicolumn{1}{|c|}{ Course } & Frequency & Percent & Rank \\
\hline BS Psychology & 15 & 36.60 & 1 \\
\hline BSE & 6 & 14.60 & 2 \\
\hline Nursing & 4 & 9.75 & 3.5 \\
\hline Hotel and Restaurant Management & 4 & 9.75 & 3.5 \\
\hline Diploma in Computer Science & 1 & 2.43 & 10.5 \\
\hline Computer Engineering & 1 & 2.43 & 10.5 \\
\hline BS Biology & 1 & 2.43 & 10.5 \\
\hline Computer Science, Meteorology, & 1 & 2.43 & 10.5 \\
\hline Assistant Teacher & 1 & 2.43 & 10.5 \\
\hline BS Civil Engineering & 2 & 4.88 & \\
\hline Law & 1 & 2.43 & 10.5 \\
\hline Mass Communication & 1 & 2.43 & 10.5 \\
\hline BS Civil Engineering, BS Accountancy & 1 & 2.43 & 10.5 \\
\hline Tourism, Criminology & 2 & 4.88 & \\
\hline Total & 41 & & 5.5 \\
\hline No Answer & 6 & & \\
\hline Total & 47 & 100.00 & \\
\hline
\end{tabular}

The table shows that in terms of first choice course, the respondents have chosen to pursue BS Psychology because it was their first love and some of them have loved ones or have known alumni who are successful in this field of specialization.

Since, six respondents did not respond to the question, their percentage was not considered.

This implies that one out of three graduates of BS Psychology intended to pursue the course even before entering in college, since, they find this discipline as in-demand to the labor market.

This confirms an article from the United States Bureau of Labor Statistics (www.bls.gov) that Bachelor of Science in Psychology programs offer students foundational knowledge in analytical reasoning, cognition, statistics and subfields of psychology. Furthermore, students can improve their skills in technical writing, critical thinking and research. 
Table 6:- Frequency, Percentage and Rank Distribution of the Respondents in Terms of Source of College Finances

\begin{tabular}{|l|c|c|c|}
\hline Source of Finances & Frequency & Percent & Rank \\
\hline Support from parents & 36 & 76.60 & 1 \\
\hline Self- Support & 2 & 4.30 & 3 \\
\hline Scholarship & 9 & 19.10 & 2 \\
\hline Total & 47 & 100.00 & \\
\hline
\end{tabular}

As shown in the table, in terms of source of college finances, parents provide full support to their children. This was followed by scholarship grants from public and/or private institutions either full or partial financial aid. Last in rank is engaging in work while studying in order to suffice the need for academic endeavor.

This entails that parents place considerably high value on education to prepare their children's' future because they believe it would be the legacy that they can contribute to them.

Table 7:- The Respondents in Terms of Personal Monthly Income

\begin{tabular}{|l|c|c|c|}
\hline \multicolumn{1}{|c|}{ Personal Monthly Income } & Frequency & Percent & Rank \\
\hline below Php 5000.00 & $\mathbf{6}$ & $\mathbf{1 5 . 7 9}$ & $\mathbf{4}$ \\
\hline Php 5001.00 - 8000.00 & 8 & 21.05 & 2.5 \\
\hline Php 8001.00 - 11000.00 & 8 & 21.05 & 2.5 \\
\hline Php 11001.00 above & 16 & 42.11 & 1 \\
\hline Total & 38 & & \\
\hline No Answer & 9 & & \\
\hline Total & 47 & 100.00 & \\
\hline
\end{tabular}

The above table shows that in terms of current monthly income, respondents are receiving just enough for their daily needs. This was followed by lower revenue, for the fact that, most of them are not yet permanent in their work.

Since, nine (9) of the respondents did not reply to the question, their percentage was not considered.

This implies that majority of the employed BS Psychology graduates are above poverty line.

This affirms a study made by the National Economic and Development Authority (NEDA) that every Filipino family consisting five members should be earning on the average a combined monthly income of Php 7,019 in order to meet the basic needs.

Status of BS Psychology Graduates with Respect to Their Employer, Employment Status, First Job Title, Nature of Work, Job Hunting Period, and How They Find Their First Job, Reason for Getting Current Job and Reason for Accepting the Current Job

Table 8:- Frequency, Percentage and Rank Distribution of the Respondents with Respect to Employer

\begin{tabular}{|l|l|c|c|c|}
\hline \multicolumn{1}{|c|}{ Employer } & Frequency & Percent & Rank \\
\hline & Work for private establishment/institution & 32 & 84.21 & 1 \\
\hline & $\begin{array}{l}\text { Work for government/ government } \\
\text { corporation }\end{array}$ & 5 & 13.16 & 2 \\
\hline & $\begin{array}{l}\text { Work w/pay on own family operated farm } \\
\text { or business }\end{array}$ & 1 & 2.63 & 3 \\
\hline Notal & 38 & & \\
\hline Notal & & 9 & & 100.00 \\
\hline
\end{tabular}

The table shows that the respondents preferred to be employed in private establishments or institutions rather than in public or government corporations because of its flexible coverage in the industrial and clinical settings. However, only 1 or 2.63 percent work with pay on own family operated farm or business. 
This denotes that majority of the BS Psychology graduates are offered to work in private institutions or establishments due to numerous vacant positions related to the course.

This affirmed an article titled Bachelor of Science Degree: An Overview which was excerpted from a website that jobs and opportunities in the private sector are target-driven, which means there were certain goals to be fulfilled by each employee.

Table 9:- Frequency, Percentage and Rank Distribution of the Respondents with Respect to Employment Status

\begin{tabular}{|c|c|c|c|c|}
\hline \multicolumn{2}{|r|}{ Employment Status } & Frequency & Percent & Rank \\
\hline & Permanent job/ business/ unpaid family work & 13 & 34.20 & 2 \\
\hline & $\begin{array}{l}\text { Short-term or seasonal or casual or contractual } \\
\text { job/business/ unpaid family work }\end{array}$ & 23 & 60.50 & 1 \\
\hline & $\begin{array}{l}\text { worked for different employer on a day to day or } \\
\text { week to week basis }\end{array}$ & 2 & 5.30 & 3 \\
\hline & Total & 38 & & \\
\hline No Answer & & 9 & & \\
\hline \multicolumn{2}{|l|}{ Total } & 47 & 100.00 & \\
\hline
\end{tabular}

As seen in the table, in terms of nature of employment due to implementation of contractualization in the labor market, short-term or seasonal or casual or temporary status is common, whereas, work for different employer on a day to day or week to week basis is the least choice of the BS Psychology graduates.

Since nine (9) of the respondents did not reply to the item, their percentage was not considered.

This implies that majority of the BS Psychology graduates are working, though, as contractual or casual status due to restricted permanent positions both in public and private institutions. This may also be accounted to end of contract from one employer to another and to the fast turn-over of human resources for various reasons.

Table 10:- Frequency, Percentage and Rank Distribution of the Respondents with Respect to First Job Title

\begin{tabular}{|c|c|c|c|c|c|c|c|}
\hline $\begin{array}{l}\text { Job Related to } \\
\text { Psychology }\end{array}$ & $\mathbf{F}$ & $\%$ & $\mathbf{R}$ & $\begin{array}{c}\text { Job Not Related to } \\
\text { Psychology }\end{array}$ & $\mathbf{F}$ & $\%$ & $\mathbf{R}$ \\
\hline $\begin{array}{l}\text { HR Assistant/ HR Office } \\
\text { Staff }\end{array}$ & 15 & 57.59 & 1 & Telemarketer/Customer Care & 4 & 25.00 & 1 \\
\hline Development Officer & 2 & 7.69 & 3.5 & Cashier & 3 & 18.75 & 2.5 \\
\hline Admin Officer & 2 & 7.69 & 3.5 & Office Staff & 3 & 18.75 & 2.5 \\
\hline Training Officer & 1 & 3.85 & 6.5 & Crew & 2 & 12.5 & 4 \\
\hline Relationship manager & 1 & 3.85 & 6.5 & Saleslady & 1 & 6.25 & 6.5 \\
\hline $\begin{array}{l}\text { Teacher ( Early } \\
\text { Childhood and } \\
\text { Psychology Instructor ) }\end{array}$ & 3 & 11.54 & 2 & Independent Checker & 1 & 6.25 & 6.5 \\
\hline Social Welfare Aide & 1 & 3.85 & 6.5 & Brand Ambassador & 1 & 6.25 & 6.5 \\
\hline HR Supervisor & 1 & 3.85 & 6.5 & Asst. Restaurant Manager & 1 & 6.25 & 6.5 \\
\hline Sub-total & 26 & 100.00 & & & 16 & 100.00 & \\
\hline No Answer & \multicolumn{7}{|c|}{5} \\
\hline Grand Total & & & & 42 & \multicolumn{3}{|c|}{100.00} \\
\hline
\end{tabular}

The above table shows that in terms of first job title, graduates of Psychology desire jobs which are related to the field such as HR Assistant or HR Office Staff, Teacher, Training Officer, HR Supervisor, Relationship Manager, Independent Checker, Social Welfare Aide and the like. On the contrary, some also accepted offers for being Salesperson, Brand Ambassador, Assistant Restaurant Manager 3, though, those are not related to the discipline and in order for them to make a living.

Since five of the respondents did not respond to the question, their percentage was not considered.

This implies that only few Psychology graduates are engaged in the clinical setting because of higher standards and 
further studies are needed to practice in the field due to the regulation set by the Professional Regulation Commission, thru the Republic Act 1009 or known as the Psychology Law of 2009.

This confirmed that students who obtain a BS degree in Psychology may work in mental health facilities, government or business, but they will not be qualified for jobs as professional psychologists without further education.

Table 11:- Frequency, Percentage and Rank Distribution of the Respondents with Respect to Nature of Work (According to Field of Specialization)

\begin{tabular}{|l|l|c|c|c|}
\hline \multicolumn{2}{|l|}{ Nature of Work } & Frequency & Percent & Rank \\
\hline Valid & Manual & 3 & 7.89 & 4 \\
\hline & Clerical & 14 & 36.84 & 2 \\
\hline \multirow{3}{*}{ Nechnical/Professional } & 17 & 44.74 & 1 \\
\cline { 2 - 5 } & Managerial/Supervisory & 4 & 10.53 & 3 \\
\hline & Total & 38 & & \\
\hline Total & & 9 & & \\
\hline
\end{tabular}

It can be gleaned from the table that with respect to nature of work, Psychology alumni are aspiring to occupy technical/professional career. This was followed by clerical managerial or supervisory tasks. In contrast, manual type of work or those in the production is their least preferred due to its non-relevance to the field.

Since nine (9) of the respondents did not answer, their percentage was not considered.

This implies that four (4) out of 10 BS Psychology graduates are engaged in technical or professional work which have opportunities for professional development. This confirms that Psychology graduates may work in human resources or communications, while further education will open paths toward clinical practice and research.

Table 12:- Frequency, Percentage and Rank Distribution of the Respondents With Respect to Job Hunting Period (Month Started Looking for Work on the Year of Graduation)

\begin{tabular}{|l|l|c|c|c|}
\hline \multicolumn{2}{|c|}{ Job Hunting Period } & Frequency & Percent & Rank \\
\hline Valid & January & 3 & 6.82 & 4.5 \\
\hline & February & 2 & 4.55 & 7 \\
\hline & March & 3 & 6.82 & 4.5 \\
\hline & April & 15 & 34.09 & 1 \\
\hline & May & 10 & 22.73 & 2 \\
\hline & June & 5 & 11.36 & 3 \\
\hline & July & 2 & 4.55 & 7 \\
\hline & September & 1 & 2.27 & 9.5 \\
\hline & November & 1 & 2.27 & 9.5 \\
\hline & December & 2 & 4.55 & 7 \\
\hline & Total & 44 & & \\
\hline No Answer & & 3 & & \\
\hline Total & & 47 & 100.00 & \\
\hline
\end{tabular}

It can be noticed that with respect to job hunting period, specifically on the month the respondents started looking for work on the year of graduation, they are determined to apply and eventually work as early as April of the same year of graduation and they persevere on the succeeding months.

Since three (3) of the respondents are currently unemployed, their percentage was not considered.

This implies that five (5) out of 10 BS Psychology graduates were determined to apply their acquired knowledge and skills right after graduation. 
Table 13:- Frequency, Percentage and Rank Distribution of the Respondents with Respect to Job Hunting Period (Month Started to Work After Graduation)

\begin{tabular}{|c|c|c|c|c|}
\hline \multicolumn{2}{|c|}{ Job Hunting Period } & Frequency & Percent & Rank \\
\hline Valid & April & 5 & 12.82 & 2 \\
\hline & May & 11 & 28.20 & 1 \\
\hline & June & 3 & 7.69 & 4.5 \\
\hline & July & 3 & 7.69 & 4.5 \\
\hline & August & 2 & 5.13 & 8.5 \\
\hline & September & 2 & 5.13 & 8.5 \\
\hline & October & 4 & 10.26 & 3 \\
\hline & November & 1 & 2.56 & 12 \\
\hline & December & 2 & 5.13 & 8.5 \\
\hline & January & 2 & 5.13 & 8.5 \\
\hline & February & 2 & 5.13 & 8.5 \\
\hline & March & 2 & 5.13 & 8.5 \\
\hline & Total & 39 & & \\
\hline No Answer & & 8 & & \\
\hline Total & & 47 & 100.00 & \\
\hline
\end{tabular}

As shown in the table, due to perseverance and determination, the graduates of BS Psychology exerted their effort to apply for work right after graduation since by that time they have already received their credentials like Transcript of Records and Diploma which are needed in the hiring process.

Since eight (8) of the respondents did not respond, their percentage was not considered.

This conveys that with their possessed marketable traits, four (4) out of 10 BS Psychology graduates can find a job in less than two (2) months after graduation.

This confirms that students who earn a BS in Psychology may pursue entry-level positions in Psychology-related careers. Individuals may find work in mental health facilities, halfway houses, crisis center hospitals, detention centers or psychiatric hospitals. Some graduates may find positions as psychiatric assistants and assistant directors or administrators.

Table 14:- Frequency, Percentage and Rank Distribution of the Respondents with Respect to How They Find Their First Job

\begin{tabular}{|l|l|c|c|c|}
\hline \multicolumn{2}{|c|}{ How the First Job was Found } & Frequency & Percent & Rank \\
\hline Valid & School Placement Office & 2 & 4.88 & 5.5 \\
\hline & $\begin{array}{l}\text { Registered in public } \\
\text { employment agency }\end{array}$ & 2 & 4.88 & 5.5 \\
\hline & Approach employer directly & 15 & 36.59 & 1 \\
\hline & Approach relatives or friends & 7 & 17.07 & 3 \\
\hline & Advertisements & 12 & 29.27 & 2 \\
\hline & Referral & 3 & 7.32 & 4 \\
\hline No Answer & Total & 41 & & \\
\hline Total & & 6 & 100.00 & \\
\hline
\end{tabular}

The table shows that BS Psychology graduates' continuous search for their first job paved way through direct hiring or walk-in. On the contrary, school placement and public employment agency were the least to assist them in their job-hunting.

Since six (6) of the respondents did not reply to the question, their percentage was not considered. 
This indicates that walk-in application or directly approaching the employer even without prior awareness of the vacant position has been a very good strategy for four (4) out of ten (10) BS Psychology graduates to find their first job. On the other hand, the school must fortify its placement unit in order to benefit more of the graduating students.

Table 15:- The Respondents With Respect to Important Factors Influencing a Job Choice (Multiple Responses)

\begin{tabular}{|l|c|c|}
\hline \multicolumn{1}{|c|}{ Factors Influencing a Job Choice } & Frequency & Rank \\
\hline Wage & 40 & 2 \\
\hline Work location (Metro Manila, big cities, overseas etc.) & 18 & 9 \\
\hline Housing benefit & 14 & 10 \\
\hline Access for further education & 12 & 12 \\
\hline Promotion possibilities & 13 & 11 \\
\hline Extra income generating opportunities & 37 & 3.5 \\
\hline Proximity to family and friends & 42 & 1 \\
\hline $\begin{array}{l}\text { Professional environment, defined as the number of colleagues or with } \\
\text { the same or higher level of education }\end{array}$ & 9 & 14 \\
\hline Workload/working hours & 37 & 3.5 \\
\hline Sector (Public, Private for-profit, NGO etc.) & 11 & 13 \\
\hline Recognition from supervisor or boss & 25 & 7 \\
\hline $\begin{array}{l}\text { Education opportunities/possibility of } \\
\text { upgrading qualifications for skills }\end{array}$ & & \\
\hline $\begin{array}{l}\text { Reputation of company/institution urbanity } \\
\text { ( within big cities, outside big cities) }\end{array}$ & 19 & \\
\hline Infrastructure (internet/mobile connection, electricity) & & \\
\hline Health insurance support & 7 & \\
\hline
\end{tabular}

The table indicates that with respect to important factors influencing a job choice, professional environment, defined as the number of colleagues or with the same or higher level of education ranked first with a mean of 42 for multiple responses. This was followed by wage, with the frequency of 40. Next in rank were proximity to family and friends and sector as to private or public, with the frequency of 37 for both. On the other hand, infrastructure ranked last with the frequency of seven (7).

This point towards considering physical and social environment in choosing a job since BS Psychology graduates want to establish a career which is for a longer period of time or for a lifetime.

Table 16:- Frequency, Percentage and Rank Distribution of the Respondents with Respect to Reason for Getting Their Current Job

\begin{tabular}{|c|c|c|c|c|}
\hline \multicolumn{2}{|c|}{ Reason for Getting Their Current Job } & \multirow{2}{*}{$\frac{\text { Frequency }}{4}$} & \multirow{2}{*}{$\begin{array}{c}\text { Percent } \\
9.76\end{array}$} & \multirow{2}{*}{$\begin{array}{c}\text { Rank } \\
4.5\end{array}$} \\
\hline & University Ranking & & & \\
\hline & Work Experience & 7 & 17.07 & 2 \\
\hline & Personal Connection & 5 & 12.20 & 3 \\
\hline & $\begin{array}{l}\text { Occupational Skill/s Practical } \\
\text { Exercise }\end{array}$ & 16 & 39.02 & 1 \\
\hline & Language Skills & 4 & 9.76 & 4.5 \\
\hline & IT Skills & 2 & 4.88 & 6.5 \\
\hline & Gender & 2 & 4.88 & 6.5 \\
\hline & Religion & 1 & 2.44 & 8 \\
\hline & Total & 41 & & \\
\hline No Answer & & 6 & & \\
\hline \multicolumn{2}{|l|}{ Total } & 47 & 100.0 & \\
\hline
\end{tabular}

The table shows that, with respect to reason for getting the current job, the respondents believed it was due to their occupational skills and/or results of practical exercises, related work experience/s personal connection or linkages. On the contrary, religion has nothing to do with their current job. 
Since six (6) of the respondents did not respond, their percentage was not considered.

This involves that four (4) out of ten (10) BS Psychology graduates attribute the job offer to their competent talents, skills and hands-on activities which are essential in the world of work.

Table 17:- Frequency, Percentage and Rank Distribution of the Respondents with Respect to Reason for Accepting Their Current Job

\begin{tabular}{|l|l|c|c|c|}
\hline \multicolumn{2}{|c|}{ Reason/s for Accepting Their Current Job } & Frequency & Percent & Rank \\
\hline & matches my qualification & 12 & 29.27 & 1 \\
\hline & matches my interest & 8 & 19.51 & 3 \\
\hline & financial reason & 10 & 24.39 & 2 \\
\hline & pressure from parents/relatives & 6 & 14.63 & 4 \\
\hline & pressure from friends/classmates/peers & 5 & 12.20 & 5 \\
\hline & Total & 41 & & \\
\hline No Answer & & 6 & & \\
\hline Total & & 47 & 100.00 & \\
\hline
\end{tabular}

The table shows that with respect to reason for accepting the current job, the respondents firmly trust that it matches their qualification, followed by financial motive and concentration. On the contrary, pressure from friends/classmates/peers were the least considered.

Since six (6) of the respondents did not respond, their percentage was not considered.

This suggests that only three (3) out ten (10) BS Psychology graduates consider their job as matched to their qualification. This might be linked to the economic status, since they are considering the finances and grab the opportunity as new in the work force.

This is in connection to a study that educational institutions employed 29 percent of psychologists in positions other than teaching, such as counseling, testing, research, and administration. Government agencies at the State and local levels employed psychologists in public hospitals, clinics, correctional facilities, and other settings.

Extent the Course Has Developed the BS Psychology Graduates with Respect to Critical Thinking Skills, Ability to Solve Complex Problems, Ability to Work with Others, Confidence to Learn Independently, Written Communication Skills, Spoken Communication Skills, Knowledge of the Field and Development of Work-related Knowledge and Skills

Table 18:- Extent of the BS Psychology Course Has Developed the Graduates

\begin{tabular}{|l|c|c|c|}
\hline \multicolumn{1}{|c|}{ Skills } & $\begin{array}{c}\text { Weighted } \\
\text { Mean }\end{array}$ & Rank \\
\hline Critical Thinking Skills & 4.04 & A Lot Contributory & 4 \\
\hline Ability to Solve Complex Problems & 4.09 & A Lot Contributory & 3 \\
\hline Ability to Work With Others & 4.47 & Very Much Contributory & 1 \\
\hline Confidence to Learn Independently & 4.40 & Very Much Contributory & 2 \\
\hline Written Communication Skills & 3.87 & A Lot Contributory & 8 \\
\hline Spoken Communication Skills & 3.91 & A Lot Contributory & 7 \\
\hline Knowledge of the Field & 4.02 & A Lot Contributory & 6 \\
\hline Development of Work-related Knowledge and Skills & 4.02 & A Lot Contributory & 5 \\
\hline Average Weighted Mean & 4.10 & A Lot Contributory & \\
\hline
\end{tabular}

The above table reflects that the BS Psychology course has developed the graduates' ability to work with others ranked first with a weighted mean of 4.47, interpreted as very much contributory. This was followed by having confidence to learn independently with a weighted mean of 4.40 with a verbal interpretation of very much 
contributory. Third in rank was the ability to solve complex problems with a weighted mean of 4.09 , interpreted to have a lot contributory, whereas, written communication skills and spoken communication skills, ranked seventh and eighth with 3.87 and 3.91 weighted means, both interpreted as lot contributory.

Thus, the course has contributed a lot to the employment of the graduates with its average weighted mean of 4.10.

This implies that BS Psychology as a course lives by its goal to provide students with rigid training in the three settings or fields in Psychology namely; educational, industrial and clinical. Furthermore, it serves the objective for the students to acquire sufficient knowledge and skills needed to qualify for a position in educational, industrial and clinical setting as a Psychology practitioner or its related position.

Extent of Influence of the Course on the Overall College Life Experience

Table 19:- Extent of Influence of the BS Psychology Course on the Overall College Experience of the Respondents

\begin{tabular}{|c|c|c|c|}
\hline College Life Experience & $\begin{array}{l}\text { Weighted } \\
\text { Mean }\end{array}$ & V.I. & Rank \\
\hline $\begin{array}{l}\text { has helped to connect what have learned in the classroom with real life } \\
\text { situations. }\end{array}$ & 3.87 & Agree & 4 \\
\hline $\begin{array}{l}\text { has helped translate what have learned inside the classroom into } \\
\text { actions. }\end{array}$ & 4.02 & Agree & 3 \\
\hline has had a positive influence on intellectual growth and interest in ideas. & 4.23 & Strongly Agree & 1 \\
\hline has had a positive influence on personal growth, attitudes, and values. & 4.21 & Strongly Agree & 2 \\
\hline Average Weighted Mean & 4.09 & Agree & \\
\hline
\end{tabular}

The table indicates that with regard to the overall college experience, the BS Psychology graduates strongly agree that the course has had a positive influence on intellectual growth and interest in ideas, for it ranked first with a weighted mean of 4.23 . With a small gap, this was followed by positive influence on personal growth, attitudes and values with a weighted mean of 4.21 , also interpreted as strongly agree. Rank 3 was translating what have learned inside the classroom into actions, with a weighted mean of 4.02, verbally interpreted as agree. Last in rank was to connect what were learned in the classroom with real life situations, which got a mean of 3.87 and verbally interpreted as agree.

Inferring thus, with an average weighted mean of 4.09, majority of the graduates are agreeable that the course has positive influence on themselves especially on their day-to-day living like meeting demands, establishing and maintaining good relationships with people, adjusting to a certain change, understanding or considering individual difference and the like .

This affirms that BS Psychology program lives by its goal and objectives to produce competent and value-laden graduates.

Extent of Life Satisfaction of the BS Psychology Graduates

Table 20:- The Extent of Life Satisfaction of the BS Psychology Graduates

\begin{tabular}{|l|c|c|c|}
\hline \multicolumn{1}{|c|}{ Life Satisfaction Criteria } & $\begin{array}{c}\text { Weighted } \\
\text { Mean }\end{array}$ & V.I. & Rank \\
\hline The home in which you live & 4.34 & Totally Satisfied & 2 \\
\hline Your current job your employment opportunities & 3.95 & Satisfied & 6 \\
\hline Your financial situation & 3.91 & Satisfied & 8 \\
\hline How safe you feel & 4.38 & Totally Satisfied & 1 \\
\hline Feeling part of your local community & 3.91 & Satisfied & 7 \\
\hline Your health & 4.30 & Totally Satisfied & 3 \\
\hline The national government & 3.36 & Less Satisfied & 9 \\
\hline The amount of free time that you have & 4.00 & Satisfied & 5 \\
\hline Your life as a whole & 4.18 & Satisfied & 4 \\
\hline Average Weighted Mean & 4.06 & Satisfied & \\
\hline
\end{tabular}


It could be gleaned from the table above that with regard to life satisfaction, "how safe you feel," ranked first with a weighted mean of 4.38, interpreted as totally satisfied. Next in rank was "The home in which you live," with a weighted mean of 4.34 with a verbal interpretation of totally satisfied. Third in rank was "your health," with a weighted mean of 4.30, also interpreted as totally satisfied. In contrast to those criteria, "the national government" ranked as the least among them with a mean of 3.36, with a verbal interpretation of less satisfied.

With an average weighted mean of 4.06, this implies that majority of the graduates are contented with their present life as they try to accept the realities of life like meeting demands, using advanced technology, increasing prices and continuing the journey of life, since, they have learned that the principles of Psychology can be applied in any endeavor.

\section{Course(s) Training Program(s) Need(s) to be Included in the Curriculum to Enable BS Psychology Graduates to Compete in the Labor Market}

Table 21:- Frequency and Rank Distribution on Course(s) or Training Program(s) Need(s) to be Included in the BS Psychology Curriculum (Multiple Responses)

\begin{tabular}{|l|c|c|}
\hline \multicolumn{1}{|c|}{ Training Programs } & Frequency & Rank \\
\hline Communication Courses & 24 & 2 \\
\hline IT Courses & 20 & 3 \\
\hline Human Resource Courses & 34 & 1 \\
\hline Language Courses & 12 & 5 \\
\hline Occupational Skills/Practical & 15 & 4 \\
\hline
\end{tabular}

The table reflects that with regard to the course/s or training programs that need to be included in the BS Psychology curriculum, human resources courses ranked first, since most of the graduates are in the industrial setting. This was followed by communication courses and Information Technology which are part of the modernization in the industry as they try to reach out to more clients using the social media context. In contrast, they did not consider engaging in a Language course because they do not have foreigner clients who are non-usage of English Language.

This implies that most of the BS Psychology graduates who are employed in the industrial setting feel the essence of having more human resource-related subjects and relevant trainings in order to meet the changing demands at work.

This confirms the objective of the course, that graduates of this program, are expected to acquire and develop sufficient knowledge and skills needed to qualify for a position related to the discipline.

\section{Summary and Conclusions:-}

Based on the analysis of data, the findings were as follows:

\section{Profile of the Respondents:-}

1. In terms of sex, female graduates ranked first with frequency of 31 or 66 percent, whereas, there were only 16 males or 34 percent.

2. In terms of age, the respondents who belonged to 26-29 years old ranked firs with the frequency of 17 or 41.50 percent. This was followed by those 22-25 years old with the frequency of 15 or 36.60 percent. Third in rank were those below 21 years old with the frequency of 6 or 14.60 percent. On the other hand, 30 and above years old ranked last with the frequency of 3 or 7.3 percent.

3. In terms of civil status, single respondents outnumbered the married status with the frequency of 30 or 63.80 percent, on the other hand, 17 or 36.20 percent were married.

4. In terms of first choice course, the respondents have chosen to pursue BS Psychology with a frequency of 15 or 36.60 percent. This was followed by BSE with 6 or 14.60 percent. Next in rank were Nursing and Hotel and Restaurant management with the frequency of 4 or 9.75 percent. On the contrary, various courses like Computer Science, Meteorology, Mass Communication BS Biology and others ranked 10.5 with a frequency of one (1) respectively.

5. In terms of source of college finances, support from parents ranked first with a frequency of 36 or 76.60 percent. This was followed by scholarship grants with 9 or 19.10 percent. Last in rank is being a self-supporting student, with a frequency of 2 or 4.30 percent. 
6. In terms of current monthly income, respondents who are receiving Php 11,001.00 and above ranked first with a frequency of 16 or 42.11 percent. This was followed by Php 8,001- 11,000 and Php 5,001- 8,000 respectively with 8 or 21.05 percent. Last in rank are those respondents receiving below Php 5,000.

Status of BS Psychology Graduates with Respect to Their Employer, Employment Status, First Job Title, Nature of Work, Job Hunting Period, and How Did they Find Their First Job, Reason for Getting Current Job and Reason for Accepting the Current Job

With respect to employment status, short-term or seasonal or casual or contractual job/business/ unpaid family work ranked first with a frequency of 23 or 60.5 percent. This was followed by permanent job/ business/ unpaid family work with 13 or 34.20 percent, whereas, only 2 or 5.3 percent worked for different employer on a day to day or week to week basis, ranked as the least.

With respect to first job title, HR Assistant or HR Office Staff ranked first with a frequency of 15 or 35.71 percent. Second in rank was being Telemarketer or Customer Care with a frequency of 4or 9.52 percent. Fourth in rank were Office Staff, Cashier and Teacher with a frequency of 3 or 7.14 percent respectively. On the contrary, numerous first job titles like Sales Lady, Brand Ambassador, Relationship Manager, Independent Checker, Social Welfare Aide, Assistant Restaurant Manager 3, Training Officer, Supervisor ranked last, with a frequency of 1 or 2.38 percent each respectively.

With respect to nature of work, technical/professional ranked first with a frequency of 17 or 44.74 percent. This was followed by clerical with a frequency of 14 or 36.84 . Third in rank was managerial or supervisory with a frequency of 4 or 10.53 percent. In contrast, manual type of work ranked last with a frequency of 3 or 7.89 percent.

With respect to job hunting period, specifically on the month the respondents started looking for work on the year of graduation, April ranked first with a frequency of 15 or 34.09 percent. This was followed by the month of May with a frequency of 10 or 22.73 percent. Third in rank was the month of June with a frequency of 5 or 11.36 percent. Lastly, were September and November, with frequency of 1 or 2.27 percent each respectively.

With respect to job hunting period, specifically on the month started to work after graduation, month of May ranked first, with a frequency of 11 or 28.20 . Second in rank was April, with a frequency of five (5) or 12.82 percent. This was followed by the month of October with a frequency of four (4) or 10.26 percent, however, the month of November ranked last with a frequency of one (1) or 2.56 percent.

With respect to how did they find their first job, the respondents who approached employer directly ranked first with a frequency of 15 or 36.59 percent. Second in rank was through advertisements with a frequency of 12 or 29.27 percent. This was followed by those who approached their relatives and friends with a frequency of seven (7) or 17.07 percent. On the contrary, school placement and public employment agency ranked the least, with frequency of two (2) or 4.88 percent each.

With respect to important factors influencing a job choice, professional environment, defined as the number of colleagues or with the same or higher level of education ranked first with 42 multiple responses. This was followed by wage, with the frequency of 40 . Next in rank were proximity to family and friends and sector as to private or public, with the frequency of 37 for both. On the other hand, infrastructure ranked last with the frequency of seven (7).

With respect to reason for getting the current job, the respondents who thought it was due to their occupational skills and/or results of practical exercises ranked first with a frequency of 16 or 39.02 percent. Second in rank was related work experience/s with a frequency of seven (7) or 17.07 percent. This was followed by their personal connection or linkages with a frequency of five (5) or 12.20 percent. On the contrary, religion ranked the least, with a frequency of 1 or 2.44 percent.

With respect to reason for accepting the current job, the respondents who thought it matches their qualification ranked first with a frequency of 12 or 29.27 percent. Second in rank was financial reason with a frequency of ten (10) or 24.39 percent. This was followed by those who considered their interest with a frequency of 8 or 19.51 
percent. On the contrary, pressure from friends/classmates/peers ranked the least, with a frequency of five (5) or 12.20 percent

\section{Extent the Course Has Developed the BS Psychology Graduates:-}

The BS Psychology course has developed the students to work with others ranked first with a weighted mean of 4.47 , interpreted as very much contributory. This was followed by having confidence to learn independently with a weighted mean of 4.40 with a verbal interpretation of very much contributory. Third in rank was the ability to solve complex problems with a weighted mean of 4.09, interpreted to have a lot contributory, whereas, written communication skills and spoken communication skills, ranked seventh and eighth with 3.87 and 3.91 weighted means, both interpreted as lot contributory.

\section{Extent of Overall College Life Experience:-}

With regard to the overall college experience, the BS Psychology graduates strongly agree that the course has had a positive influence on intellectual growth and interest in ideas, for it ranked first with a weighted mean of 4.23 . With a small gap, this was followed by positive influence on personal growth, attitudes and values with a weighted mean of 4.21, also interpreted as strongly agree. Rank 3 was translating what have learned inside the classroom into actions, with a weighted mean of 4.02, verbally interpreted as agree. While, last in rank was to connect what have learned in the classroom with real life situations, which got a mean of 3.87 and verbally interpreted as agree.

\section{Extent of Life Satisfaction of the BS Psychology Graduates:-}

With regard to the extent of life satisfaction, "how safe you feel," ranked first with a weighted mean of 4.38, interpreted as totally satisfied. Next in rank was "The home in which you live," with a weighted mean of 4.34 with a verbal interpretation of totally satisfied. Third in rank was "your health," with a weighted mean of 4.30, also interpreted as totally satisfied. In contrast to those criteria, "the national government" ranked as the least among them with a weighted mean of 3.36 , with a verbal interpretation of less satisfied.

Course(s), Training Program(s) Need(s) to be Included in the Curriculum:-

With regard to the course/s or training programs need to be included in the BS Psychology curriculum, human resources courses ranked first with the frequency of 34. This was followed by communication courses with 24 and Information Technology Courses with 20. In contrast, Language Courses ranked the least with the frequency of 12.

\section{Conclusions:-}

Based on the findings of the study, it can be concluded that:

Majority of the respondents were female, trainable, young adults, responsible single, have chosen to pursue BS Psychology as their first choice course, financially supported by parents in college and belonged to above poverty line.

Majority of the BS Psychology graduates are offered to work in private institutions or establishments due to numerous vacant positions related to the course; are employed in contractual or casual status due to limited permanent positions both in public and private institutions; with first job title of an HR Assistant or HR Office Staff; involved in technical or professional work which have opportunities for professional development; determined to apply their acquired knowledge and skills right after graduation; got hired in less than 2 months after graduation as walk-in aspirant or direct application; whose job choice was influenced by professional environment; attribute the job offer to their competent talents, skills and hands-on activities; consider their occupation as complemented to their qualification.

The graduates believe that BS Psychology course has developed them to be competent team player; are agreeable that the course has optimistic impact on them; are contented with their present life.

In order to meet the varying demands in diverse workplace, they feel the essence of having more human resource related subjects and relevant trainings to be included in the curriculum.

\section{Implications and Recommendations:-}

Based on the conclusions, the following recommendations are hereby offered: 
1. The University should encourage and prepare more BS Psychology graduates to take and pass relevant government examinations like Civil Service Professional Exam, Licensure Examination for Psychometrician and/or TESDA National Certification in order to have security of tenure.

2. The University/Campus should strengthen the school placement to be the initial source of finding a job before and after graduation.

3. The University thru its administrators should review the program by having additional Human Resources related-subject/s and improve facilities of the college, especially the Psychology Laboratory Room to enhance more of the students' knowledge and skills which are needed in the field.

4. The professors are highly encouraged to include in the teaching-learning encounters the most relevant and authentic lessons, activities and other scenarios that could help the students find and establish strong connection of what have been learned in the classroom with the real life situations.

5. A parallel study might be conducted using other variables like eligibility and length of service to verify the results.

\section{Literature Cited:-}

1. Career in Psychology. Retrieved from www. exeter.aca.uk/ undergraduate/degrees/psychology/career

2. The Future of Undergraduate Psychology in the United Kingdom. 2011. Higher Education Academy Psychology Network. Retrieved from http://psychology.about.com.

3. U.S. Bureau of Labor Statistics. Retrieved from www.bls.gov

4. Bachelor of Science in Psychology Degree Overview. Retrieved from http://educationportal.com/articles/Bachelor_of_Science_BS_Psychology_Degree_Overview.html.

5. Retrieved from www.ched.gov.ph.

6. About Tracer Study. Retrieved from www.academia.edu.

7. CHED's Tracer Study. Retrieved from http://cscresearch.wordpress.com.

8. Job Mismatch in the Philippines. Retrieved from https://ph.news.yahoo.com/graduate-tracer-study-seeksaddress-job-mismatch-055852030.html.

9. Donalie C. Evangelista, et.al. 2015. An Undergraduate Thesis. A Tracer Study of the Graduates of Bachelor of Arts Major in Political Science of the University of Rizal System Pililla, Academic Years 2008-2013. www.neda.gov.ph. 